\title{
ANALISIS SIKAP DAN NORMA SUBYEKTIF TERHADAP PERILAKU KONSUMEN UNTUK MEMBELI SEPEDA MOTOR HONDA ABSOLUTE REVO (Studi Kasus: Masyarakat Kelurahan Bantan, Kecamatan Medan Tembung-Medan)
}

\author{
Ria Veronica Sinaga \\ Universitas Katolik Santo Thomas Medan Jl. Setia Budi No. 479F, 20132, Indonesia \\ e-mail: riaveronicas@gmail.com
}

\begin{abstract}
This study aims to determine and analyze the subjective attitudes and norms of consumer behavior to buy a Honda Absolute Revo motorcycle for the people of Bantan Village, Medan Tembung Sub-District. The benefits of research are to provide input for companies in order to formulate marketing strategies and contribute to researchers in the field of marketing science. Number of samples 96 respondents. Data collection techniques used were interviews, questionnaires and documentation. The data analysis method used is the Behavioral Intention (BI) Model. Based on the results of the study obtained the equation of interest in behavior (BI) as follows: $B I=W 1 A b+W 2 S N=0.61 A b+0.39 S N$. This means that greater behavioral interest is influenced by community attitudes of 0.61 (61\%) from subjective norms of $0.39(39 \%)$. Based on the description, it can be concluded that subjective attitudes and norms influence the behavior of the community in Bantan Village, Medan Tembung-Medan District in buying a Honda Absolute Revo motorcycle. We recommend that manufacturers of Honda Absolute Revo need to pay attention to the attitude of the people in buying motorbikes, especially affordable motorcycle prices, high resale prices, the excitement of fuel consumption, and ease of maintenance. Because these four attributes are the most dominant attributes affecting the attitude of the people to buy a Honda Absolute Revo motorcycle.
\end{abstract}

Keywords: Attitudes, Subjective Norms, and Consumer Behavior

\section{PENDAHULUAN}

Perkembangan ilmu pengetahuan dan teknologi yang semakin pesat pada saat ini, mendorong produsen melakukan penyempurnaan produk agar dapat bersaing dengan produk sejenis. Penyempurnaan produk dapat dilakukan dengan merubah bentuk, warna, menambah kemudahan penggunaan produk, dan karateristik lain yang membedakan produk tersebut dengan produk pesaing.

Pada umumnya konsumen menginginkan produk yang memiliki karateristik lebih cepat, lebih murah, dan lebih baik. Karateristik lebih cepat berkaitan dengan dimensi waktu, yang menggambarkan kecepatan dan kemudahan memperoleh produk yang ditawarkan oleh perusahaan. Karateristik lebih murah berkaitan dengan biaya, yang menggambarkan harga pembelian produk secara tunai dan besar cicilan produk setiap bulan. Karateristik lebih baik berkaitan dengan daya tahan produk berupa garansi yang diberikan perusahaan atas produknya.

Salah satu faktor penting yang mempengaruhi perilaku konsumen untuk membeli sepeda motor adalah sikap. Ada kecenderungan bahwa sikap sebagai faktor yang paling kuat untuk memprediksi perilaku konsumen di masa mendatang. Sikap merupakan pengaturan atau pengorganisasian proses persepsi, kognisi, emosi, dan kecenderungan bertindak atau bereaksi terhadap suatu produk yang ditawarkan perusahaan. Dengan mengetahui sikap konsumen, perusahaan dapat mengetahui sejauh mana pengaruh sikap terhadap perilaku mereka untuk membeli produk yang ditawarkan. Namun demikian, perilaku tidak hanya dipengaruhi oleh sikap saja tetapi juga dipengaruhi oleh norma subjektif. Norma subjektif menggambarkan bahwa seseorang membeli sesuatu karena pengaruh dari orang lain, yakni pengaruh orangtua, tetangga, teman, rekan bisnis, dan tenaga pemasar. 
Sikap konsumen untuk membeli sepeda motor juga dipengaruhi oleh berbagai faktor seperti warna, bentuk kerangka dan bodi sepeda motor, garansi mesin, kemudahan mengendarai, harga, harga jual kembali tinggi, keiritan pemakaian bahan bakar, bentuk lampu, tarikan mesin, kemudahan sparepart, dan kemudahan perawatan. Biasanya perilaku konsumen akan dilakukan jika kondisinya memungkinkan, yaitu: sikap konsumen tersebut positif dan menguntungkan atau norma subjektifnya juga menguntungkan.

Berdasarkan hasil pengamatan diketahui bahwa sepeda motor sejenis yang dipasarkan saat ini antara lain: Supra 125X, Honda Absolute Revo, Supra Fit X, Supra S, Vega ZR, Jupiter, Jupiter MX, Honda Automatic, Yamaha Mio, Suzuki Spin, Suzuki ZR, Smash, Shogun RR, Satria, sepeda motor Cina dan lain sebagainya. Kehadiran produk ini membuat persaingan semakin ketat dan memberikan banyak pilihan bagi konsumen. Namun keputusan konsumen untuk membeli sepeda motor bebek tersebut dipengaruhi oleh sikap dan norma subjektif. Dalam penelitian ini yang diteliti adalah Honda Absolute Revo, karena produk ini merupakan produk baru, dengan daerah penelitihan Kelurahan Bantan, Kecamatan Medan TembungMedan. Meskipun produk baru tetapi masyarakatnya telah banyak yang membelinya. Dilihat dari siklus daur hidup produk, Honda Absolute Revo berada dalam tahap pertumbuhan. Data penjualan sepeda motor Honda Absolute Revo pada Dealer Honda Berlian Bintang Mas, mulai bulan Juli 2016 - Maret 2017 di Jl. Medan-Batang Kuis, Pasar X. Disajikan pada tabel berikut:

Tabel 1. Volume Penjualan Sepeda Motor Honda Absolute Revo Pada Dealer Honda di Jl. Medan-Batang Kuis, Pasar X, Medan Bulan Juli 2016 - Maret 2017

\begin{tabular}{|l|c|c|}
\hline Bulan & $\begin{array}{c}\text { Volume Penjualan } \\
\text { (unit) }\end{array}$ & $\begin{array}{c}\text { Persentase Kenaikan atau } \\
\text { Penurunan }\end{array}$ \\
\hline Juli 2016 & 30 & - \\
\hline Agustus 2016 & 33 & $10 \%$ \\
\hline September 2016 & 39 & $18,18 \%$ \\
\hline Oktober 2016 & 34 & $-12,82 \%$ \\
\hline Nopember 2016 & 25 & $-16 \%$ \\
\hline Desember 2016 & 20 & $-4,76 \%$ \\
\hline Januari 2017 & 31 & $55,00 \%$ \\
\hline Februari 2017 & 32 & $3,23 \%$ \\
\hline Maret 2017 & $21, \pi K$ & \\
\hline
\end{tabular}

Sumber : Showroom Jl. Medan-Batang Kuis, Pasar X Tembung

Dari tabel di atas diketahui bahwa volume penjualan sepeda motor Honda Absolute Revo bulan Oktober 2016 sampai dengan bulan Januari 2017 mengalami penurunan jika dibandingkan bulan September 2016. Hal ini disebabkan persaingan antar produsen sepeda motor semakin kompetitif dan ketat, dimana setiap sepeda motor memiliki keunikan yang berbeda-beda.

Berdasarkan latar belakang masalah maka rumusan masalah adalah sebagai berikut : Bagaimana pengaruh sikap dan norma subjektif terhadap perilaku konsumen untuk membeli sepeda motor Honda Absolute Revo (Studi Kasus : Masyarakat Kelurahan Bantan, Kecamatan Medan Tembung- Medan)?

\section{TINJAUAN PUSTAKA}

\section{A. Pengertian Perilaku Konsumen}

Menurut Lamb dkk., (2001:188) perilaku konsumen adalah proses seseorang pelanggan dalam membuat keputusan membeli, untuk menggunakan dan membuang barang-barang dan jasa yang dibeli, juga termasuk faktor-faktor yang mempengaruhi 
keputusan pembelian dan penggunaan produk. Menurut Peter dan Olson (2006:6) perilaku konsumen adalah sebagai interaksi dinamis antara pengaruh dan kognisi, perilaku dan kejadian di sekitar kita dimana manusia melakukan aspek pertukaran dalam hidup mereka. Menurut Angipora (2002:119) perilaku konsumen adalah proses pengambilan dan kegiatan fisik dalam upaya memperoleh dan menggunakan barang dan jasa (evaluasi, memperoleh, menggunakan atau menentukan barang dan jasa).

Berdasarkan definisi tersebut, terdapat tiga hal penting dalam pengertian perilaku konsumen, yaitu perilaku konsumen bersifat dinamis, melibatkan interaksi dan perilaku konsumen melibatkan pertukaran. Analisis perilaku konsumen sangat penting bagi perusahaan dalam menentukan strategi pemasaran, karena apabila perusahaan tidak mengetahui perilaku konsumennya maka perusahaan dapat mengalami kesulitan dalam menentukan strategi pemasarannya.

Perilaku konsumen dinamis berarti seorang konsumen, grup konsumen serta masyarakat luas selalu berubah dan bergerak sepanjang waktu. Perubahan tersebut berpengaruh terhadap studi perilaku konsumen dan pengembangan strategi pemasaran. Dalam studi perilaku konsumen, salah satu implikasinyà adalah bahwa generalisasi perilaku konsumen biasanya terbatas untuk satu jangka waktu tertentu, produk dan individu serta grup tertentu.

Perilaku konsumen melibatkan interaksi berarti untuk memahami konsumen dan mengembangkan strategi pemasaran yang tepat, perlu memahami apa yang dipikirkan oleh konsumen (kognisi), apa yang mereka rasakan (pengaruh), apa yang mereka lakukan (perilaku), apa serta dimana (kejadian di sekitar) yang mempengaruhi serta dipengaruhi oleh apa yang dipikirkan, dirasakan dan dilakukan konsumen.

Perilaku konsumen melibatkan pertukaran artinya perilaku konsumen tetap konsisten dengan definisi pemasaran yang menekankan adanya pertukaran antara pihak perusahaan dengan pembeli. Pemasaran berperan untuk menciptakan pertukaran dengan konsumen melalui formulasi dan penerapan strategi pemasaran.

\section{B. Proses Keputusan Membeli}

Proses keputusan konsumen untuk membeli suatu produk yang ditawarkan oleh perusahaan dapat digambarkan sebagai berikut :

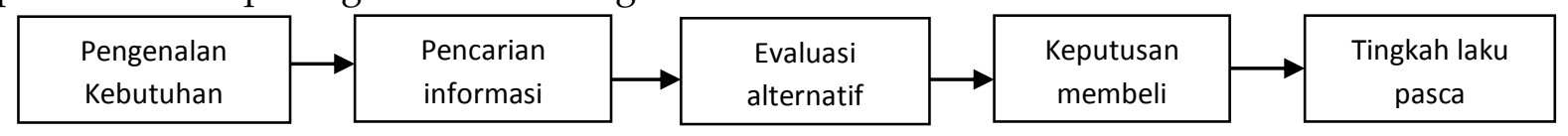

Gambar 1. Proses Keputusan Membeli

Sumber : Kotler, Philip dan Amstrong, Gary, 2004. Dasar-dasar Pemasaran, hal 24

1. Pengenalan Kebutuhan. Tahap pertama proses keputusan membeli yaitu ketika konsumen mengenali adanya masalah atau kebutuhan. Pembeli merasakan perbedaan antara keadaan nyata dan keadaan yang diinginkan. Kebutuhan dapat dipicu oleh rangsangan internal dan eksternal.

2. Pencarian Informasi. Tahap kedua dari proses keputusan membeli yaitu merangsang konsumen untuk mencari informasi lebih banyak. Konsumen dapat memperoleh informasi dari beberapa sumber seperti sumber pribadi, komersial, publik, dan pengalaman. Pengaruh relatif dari sumber informasi ini bervariasi menurut produk dan pembeli.

3. Evaluasi Alternatif. Tahap ketiga dari proses keputusan membeli yaitu ketika konsumen menggunakan informasi untuk mengevaluasi merk alternatif dalam perangkat pilihan. Pemasar harus mengetahui tentang evaluasi alternatif, yaitu bagaimana konsumen mengolah informasi sampai pada pemilihan merk.

4. Keputusan Membeli. Tahap keempat dari proses keputusan membeli yaitu ketika konsumen henar-henar membeli produk. Pada umumnya keputusan konsumen adalah 


\section{Volume 18 Nomor 2}

membeli merk yang paling disukai, tetapi dua faktor yang muncul antara niat untuk membeli dan keputusan untuk membeli.

5. Tingkah laku Pasca Pembelian. Tahap kelima dari proses keputusan membeli yaitu ketika konsumen mengambil tindakan lebih lanjut setelah membeli berdasarkan pada rasa puas atau tidak puas. Penentu puas tidaknya konsumen terletak pada hubungan antara harapan konsumen dan prestasi yang diterima dari produk. Bila produk tidak memenuhi harapan, konsumen merasa tidak puas; bila memenuhi harapan, mereka merasa puas; bila melebihi harapan, konsumen akan merasa amat puas.

\section{Sikap Konsumen}

Menurut Peter dan Olson (2001:132) pengertian sikap adalah sebagai berikut:

1. Sikap adalah suatu bentuk evaluasi atau reaksi perasaan. Sikap seseorang terhadap suatu objek adalah perasaan mendukung atau memihak maupun perasaan tidak mendukung atau tidak memihak pada objek tersebut. Secara spesifik diformulasikan sikap sebagai derajat efek positif atau negatif terhadap suatu objek psikologis.

2. Sikap merupakan suatu kesiapan untuk bereaksi terhadap suatu objek dengan cara-cara tertentu. Kesiapan yang dimaksudkan merupakan kecenderungan potensial untuk bereaksi dengan cara tertentu apabila individu dihadapkan pada suatu stimulus yang menghendaki adanya respon.

3. Sikap merupakan komponen-komponen kognitif, afektif dan konatif yang saling berinteraksi dalam memahami, merasakan dan berperilaku terhadap suatu objek. Sikap sebagai keteraturan tertentu dalam hal perasaan (afektif), pemikiran (kognitif) dan predisposisi tindakan (konatif) seseorang terhadap lingkungan sekitarnya.

Boyd, dkk (2001:135) mengatakan sikap adalah perasaan positif atau negatif tentang suatu objek (katakanlah, sebuah merk) yang mempengaruhi seseorang untuk berperilaku dalam cara tertentu terhadap objek itu.

Sikap mempunyai peranan penting dalam membentuk suatu perilaku. Pada umumnya, sikap digunakan untuk menilai efektivitas kegiatan pemasaran. Sikap merupakan evaluasi menyeluruh yang memungkinkan orang merespon secara konsisten berkenaan dengan objek atau alternatif pilihan yang diberikan. Sikap menempatkan seseorang ke dalam satu pikiran untuk menyukai atau tidak menyukai sesuatu. Ada kecenderungan untuk menganggap bahwa sikap merupakan faktor yang tepat untuk meramalkan perilaku yang akan datang. Jadi dengan mempelajari sikap, seseorang dapat menentukan apa yang akan dilakukan.

\section{Norma Subyektif}

Norma subyektif dipengaruhi oleh kelompok preferen dan motivasi dari orang lain. Kelompok preferen dan motivasi timbul dari keluarga, tetangga, teman, dan tenaga pemasar. Berdasarkan anggapan kelompok preferen ini, konsumen melakukan sesuatu karena pertimbangan kebutuhan, moral dan pertimbangan tertentu yang logis.

Menurut Ndraha (2003:18), sesuatu yang oleh seseorang dianggap dapat memenuhi kebutuhannya pada suatu waktu dan berkepentingan atasnya, maka ia dicari, diburu dan dikejar dengan menggunakan berbagai cara dan alat. Dalam hubungan itu, nilai dianggap subjektif dan ekstrinsik. Nilai ekstrinsik suatu barang berbeda menurut seseorang dibanding dengan orang lain. Oleh karena itu diupayakan agar nilai dapat diukur berdasarkan tolak ukur, standar yang objektif, yang ditetapkan oleh lembaga yang berwenang.

\section{E. Analisis Sikap dan Norma Subyektif Terhadap Perilaku Konsumen}

Tenaga pemasar harus mempelajari keinginan, persepsi, preferensi dan perilaku objek yang akan dijadikan sebagai sasaran. Perilaku konsumen perlu dipahami terlebih dahulu, sebelum merancang strategi pemasaran produk yang ditawarkan oleh perusahaan. 
Untuk menganalisis sikap dan norma subyektif, diperlukan sebuah model, salah satunya adalah model Multi Atribut dari Fishbein.

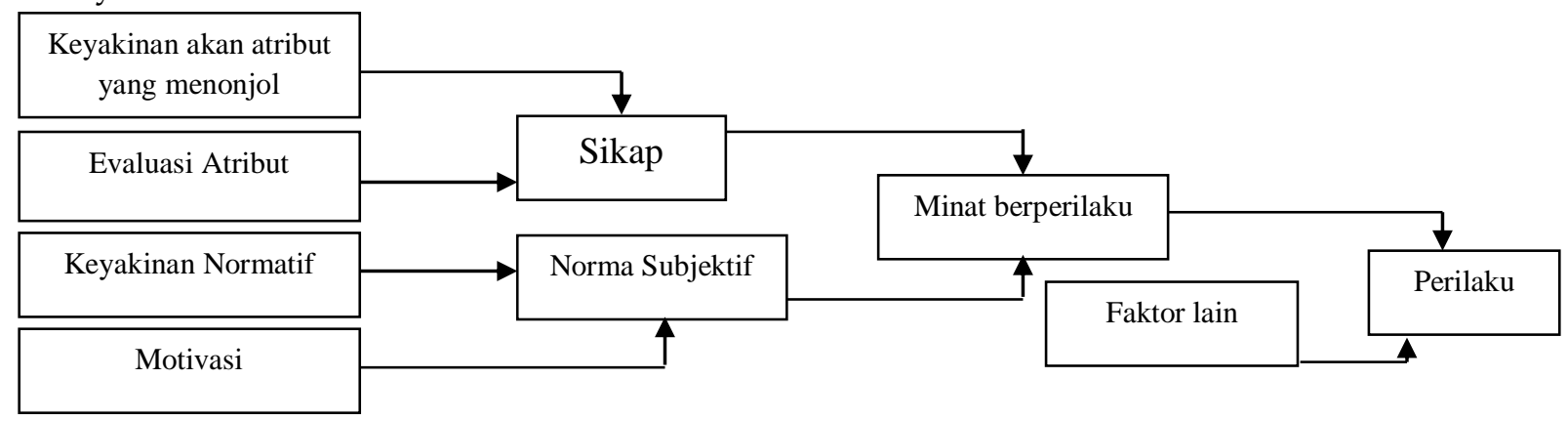

Gambar 2. Model Sikap dan Perilaku dari Fishbein

Sumber : Umar, Husein, 2001, Studi Kelayakan Bisnis, hal 77

Hubungan antara proses keputusan membeli dengan model sikap dan perilaku dari Fishbein adalah konsumen yang memiliki keyakinan terhadap suatu produk akan berusaha mengenal produk tersebut dengan mencari informasi. Informasi dapat diperoleh melalui tenaga pemasar, tetangga, sahabat, dan keluarga yang disebut sebagai norma subjektif. Dari informasi tersebut, konsumen dapat mengevaluasi atribut yang dimiliki oleh setiap produk, sehingga mereka dapat mengevaluasi dan memiliki alternatif produk yang mampu memenuhi kebutuhan dan keinginan mereka. Keputusan pembelian terhadap produk terjadi bila atribut produk yang ditawarkan sesuai dengan yang diinginkannya. Setelah konsumen membeli produk, perusahaan masih menyediakan pelayanan pasca pembelian.

Model ini digunakan dengan maksud agar diperoleh konsistensi antara sikap dan perilakunya, sehingga model Fishbein ini memiliki dua komponen, yaitu: komponen sikap dan komponen norma subjektif.

1. Komponen sikap. Komponen ini bersifat internal individu, berkaitan langsung dengan objek penelitian dan atribut-atribut langsung yang memiliki peranan yang penting dalam pengukuran perilaku. Hal ini akan menentukan tindakan apa yang akan dilakukan, dengan tidak dipengaruhi oleh faktor eksternal.

2. Komponen norma subjektif. Komponen ini bersifat eksternal individu, yang mempunyai pengaruh terhadap perilaku individu. Komponen ini dapat dihitung dengan cara mengalikan antara nilai kepercayaan normatif individu terhadap atribut dengan motivasi bersetuju terhadap atribut tersebut. Kepercayaan normatif mempunyai arti sebagai kuatnya keyakinan normatif seseorang terhadap atribut yang ditawarkan dalam mempengaruhi perilakunya terhadap objek. Sedangkan objek bersetuju merupakan motivasi seseorang untuk bersetuju dengan atribut yang ditawarkan sebagai faktor yang berpengaruh terhadap perilakunya.

Sikap dapat dihitung dengan rumus :

$$
A B=\sum_{i=1}^{n}\left(b_{\mathrm{i}}\right)\left(e_{i}\right) \text {. }
$$

Keterangan: $\mathrm{AB}=$ Sikap total individu terhadap objek tertentu

$$
\begin{array}{ll}
\mathrm{b}_{\mathrm{i}} & =\text { Kekuatan keyakinan konsumen akan objek yang dimiliki atribut } \mathrm{i} \\
\mathrm{e}_{\mathrm{I}} & =\text { Evaluasi kepercayaan individu mengenai atribut } \mathrm{i} \\
\mathrm{n} & =\text { Jumlah kriteria atribut yang relevan }
\end{array}
$$

Norma Subjektif dapat dihitung dengan rumus :

$$
S N=\sum_{j=1}^{m}(N B j)(M C j)
$$

Keterangan: $\mathrm{SN} \quad=$ Norma Subjektif

$\mathrm{NBj}=$ Keyakinan normatif individu

MCj = Motivasi konsumen

Minat Berperilaku:

$$
\mathrm{m} \text { = Banyaknya preferen yang relevan }
$$

$$
B=B I=W 1(A B)+W 2(S N)
$$

Keterangan: $B=$ Perilaku, $B I=$ Minat Berperilaku 


\author{
$\mathrm{AB}=$ Sikap terhadap pelaksanaan perilaku $\mathrm{B}$ \\ $\mathrm{SN}=$ Norma subjektif \\ $\mathrm{W} 1, \mathrm{~W} 2$ = Bobot yang ditentukan secara empiris yang menggambarkan \\ Pengaruh relatif dari komponen
}

\title{
3. METODE PENELITIAN
}

\section{A. Populasi dan Sampel}

Populasi dalam penelitian ini adalah seluruh masyarakat Kelurahan Bantan, Kecamatan Medan Tembung-Medan yang belum membeli sepeda motor Honda Absolute Revo. Sedangkan sampel dalam penelitian ini adalah sebanyak 96 orang. Penentuan sampel dilakukan secara acak sederhana. Sampel penelitian ditentukan berdasarkan kesalahan (error) maksimum yang diinginkan, dengan rumus (Supranto, 2001:113) :

$$
n=\left(\frac{Z_{\alpha / 2} \times \sigma}{\varepsilon}\right)^{2}=\left(\frac{1,96 \times 0,5}{0,1}\right)^{2}=96,04
$$

Dalam penelitian ini, tingkat keyakinan ditetapkan $95 \%\left(\alpha=5 \%\right.$, sehingga $\left.\mathrm{z}^{1 / 2} \alpha=1,96\right)$, kesalahan (error) maksimum $(\varepsilon)=0,1$ dan standar deviasi $(\sigma)=0,5$; maka jumlah sampel yang dibutuhkan $(n)=96,04$ dibulatkan menjadi 96 orang.

\section{B. Operasionalisasi Variabel}

Variabel dalam penelitian ini teridiri dari:

1. Sikap konsumen (Attitude behaviour) yaitu menggambarkan kecenderungan yang dipelajari dari seorang pembeli untuk berperilaku dalam suatu cara yang terus menerus pada hal-hal yang disenangi atau tidak disenangi untuk membeli sepeda motor Honda Absolute Revo. Sikap konsumen diukur dari :

a. Keyakinan berperilaku $\left(b_{i}\right)$. Keyakinan berperilaku (belief behaviour) yaitu suatu tanggapan yang dianut konsumen untuk membeli sepeda motor Honda Absolute Revo. Indikator pengukurannya adalah warna, bentuk kerangka dan bodi sepeda motor, garansi mesin, kemudahan mengendarai, harga, harga jual kembali tinggi, keiritan pemakaian bahan bakar, bentuk lampu, tarikan mesin, kemudahan sparepart, dan kemudahan perawatan.

b. Evaluasi akan akibat $\left(\mathrm{e}_{\mathrm{i}}\right)$. Evaluasi akan akibat (evaluation) yaitu tanggapan konsumen untuk membeli sepeda motor Honda Absolute Revo. Indikator pengukurannya adalah warna, bentuk kerangka dan bodi sepeda motor, garansi mesin, kemudahan mengendarai, harga, harga jual kembali tinggi, keiritan pemakaian bahan bakar, bentuk lampu, tarikan mesin, kemudahan sparepart, dan kemudahan perawatan.

2. Norma Subjektif (SN). Norma subjektif (subjective norm) yaitu gagasan orang lain yang menghendaki konsumen untuk membeli sepeda motor Honda Absolute Revo. Norma subjektif diukur dari :

a. Keyakinan normatif (NBj). Keyakinan normatif (norm behaviour) yaitu pengaruh orang lain terhadap konsumen untuk membeli sepeda motor Honda Absolute Revo. Indikator pengukurannya adalah orangtua, tetangga, teman, rekan bisnis, dan tenaga pemasar.

b. Motivasi (MCj). Motivasi (motivation) yaitu dorongan yang kuat dari kelompok preferen untuk membeli sepeda motor Honda Absolute Revo. Indikator pengukurannya adalah orangtua, tetangga, teman, rekan bisnis, dan tenaga pemasar.

3. Perilaku (behaviour). Perilaku yaitu keinginan konsumen untuk membeli sepeda motor Honda Absolute Revo.

Pengukuran variabel penelitian mengacu pada skala Thurstone dengan tujuh tingkatan jawaban yaitu: sangat tidak setuju (STS), tidak setuju (TS), agak tidak setuju (ATS), ragu-ragu (RR), agak setuju (AS), setuju (S), dan sangat setuju (SS). Dengan skor $-3,-2,-1,0,1$, 
2, 3. Untuk menghindari kecenderungan sentralisasi maka alternatif jawaban ragu-ragu (skor nol) tidak digunakan dalam kuesioner.

\section{Tehnik Pengumpulan Data}

Pada penelitian ini digunakan metode pengumpulan data primer melalui metode survey, yang terdiri dari:

1. Wawancara, merupakan tehnik pengumpulan data yang menggunakan pertanyaan secara lisan kepada subyek penelitian.

2. Kuesioner, merupakan metode pengumpulan data yang diperoleh dari jawaban yang diberikan responden berdasarkan daftar pertanyaan yang telah disusun sebelumnya.

3. Dokumentasi, mengumpulkan data dari berbagai sumber yang relevan dengan topic yang diteliti seperti studi pustaka.

\section{Uji Validitas dan Reliabilitas Instrumen}

Uji Validitas berguna untuk mengetahui ketepatan hasil kuesioner. Pengujian validitas tiap butir digunakan análisis ítem yaitu mengkorelasikan skor tiap butir dengan skor total yang merupakan jumlah tiap skor butir. Tehnik korelasi untuk menentukan validitas ítem ini sampai sekarang merupakan tehnik yang paling banyak digunakan. Selanjutnya dalam memberikan interprestasi terhadap koefisien korelasi, dimana ítem yang mempunyai korelasi positif dengan kriteria (skor total) serta korelasi yang tinggi, menunjukkan bahwa ítem tersebut mempunyai validitas yang tinggi pula. Menurut Sugiyono (2005:114), “jumlah anggota sampel digunakan sekitar 30 orang". Biasanya syarat mínimum yang dianngap memenuhi syarat adalah jika nilai $r=0,30$. Jika korelasi antara butir dengan skor total kurang dari 0,30 maka butir dalam instrumen tersebut dinyatakan tidak valid. Untuk menghitung koefisien korelasi digunakan "korelasi product momento" dengan rúmus :

$$
\begin{gathered}
r_{x y}= \\
\sum X_{i} Y_{i}-\left(\sum X_{i}\right)\left(\sum Y_{i}\right) \\
\sqrt{\left\{n \sum X_{i}^{2}-\left(\sum X_{i}\right)^{2}\right\}\left\{n \sum X_{i}^{2}-\left(\sum Y_{i}\right)^{2}\right\}}
\end{gathered}
$$

Keterangan : $\mathrm{Xi}=$ skor tiap butir, $\mathrm{Yi}=$ skor total butir, $\mathrm{n}=$ jumlah responden

Uji reliabilitas berguna untuk mengetahui apakah hasil kuesioner dapat dipercaya atau tidak. Pengujian reliabilitas instrumen dapat dilakukan secara internal, yang diuji dengan menganalisis konsistensi butir-butir yang ada pada instrumen dengan tehnik tertentu.

Menurut Sugiyono (2005:122), "pengujian reliabilitas dengan internal consistency" dilakukan dengan cara mencoba instrumen sekali saja, kemudian data yang diperoleh dianalisis dengan tehnik tertentu". Hasil análisis dapat digunakan untuk memprediksi reliabilitas instrumen. Pengujian reliabilitas instrumen dilakukan dengan tehnik belah dua dari Spearmen Brown dengan rumus :

$$
r i=\frac{2 r b}{1+r b}
$$

Keterangan : ri $=$ reliabilitas internal seluruh instrumen $\mathrm{rb}=$ korelasi product momento antara belahan pertama dan kedua

Perhitungan reliabilitas pada penelitian ini menggunakan análisis yang dikembangkan oleh Alpha Cronbach. Pada uji ini dinilai reliabel jika lebih besar dari 0,5 dimana kriteria sebagai berikut :

$a \geq 0,50$ artinya instrumen reliabel

$a<0,50$ artinya instrumen tidak reliabel

Setelah dilakukan uji validitas dan reliabilitass, maka selanjutnya dilakukan análisis data.

\section{E. Metode Analisis}

Untuk mengolah data yang diperoleh dari penyebaran kuisioner digunakan Model Multi Atribut dari Fishbein (Umar, 2001:78). 
1. Model sikap

$$
A B=\sum_{i=1}^{n}\left(b_{\mathrm{i}}\right)\left(e_{i}\right)
$$

Keterangan: $\mathrm{AB}=$ Sikap total individu terhadap objek tertentu

$b_{i}=$ Kekuatan keyakinan konsumen akan objek yang dimiliki atribut $i$

$\mathrm{e}_{\mathrm{i}}=$ Evaluasi kepercayaan individu mengenai atribut $\mathrm{i}$

$\mathrm{n}=$ Jumlah kriteria atribut yang relevan

2. Mencari nilai SN (Norma Subjektif)

$S N=\sum_{j=1}^{m}(N B j)(M C j)$

Keterangan: $\mathrm{SN}=$ Norma Subjektif

$\mathrm{NBj}=$ Keyakinan normatif individu

$\mathrm{MCj}=$ Motivasi konsumen

$\mathrm{m}=$ Banyaknya preferen yang relevan

3. Model Maksud Perilaku (Behavioural Intention - BI)

$B=B I=W 1(A B)+W 2(S N)$

$W 1=\frac{G M A b}{G M A b+G M S N}$

$W 2=\frac{G M S N}{G M A b+G M S N}$

Dimana :

$G M A b=\frac{\text { Total bi+Total } i}{2 x \text { Jumlah atribut }} \quad$ GMSN $=\frac{\text { Total } \mathrm{Nbj}+\text { Total } M c j}{2 \times \text { Jumlah atribut }}$

Keterangan $: \mathrm{B}=$ Perilaku konsumen, $\mathrm{BI}=$ Maksud Perilaku, $\mathrm{AB}=$ Sikap terhadap pelaksanaan perilaku B, SN = Norma subjektif, W1, W2 = bobot ditentukan secara empiris yang menggambarkan pengaruh relatif dari komponen. GMAb $=$ Grand mean nilai sikap konsumen, GMSN = Grand mean nilai norma subjektif.

Kritetia pengujian skor sikap, norma subjektif terhadap perilaku konsumen untuk membeli sepeda motor Honda Absolute Revo digunakan range Henerson sebagai berikut :

$\begin{array}{lll}1,8<\mathrm{Ab} / \mathrm{SN} \leq 3,0 & : & \text { Sangat kuat (positif) } \\ 0,6<\mathrm{Ab} / \mathrm{SN} \leq 1,8 & : & \text { Kuat (positif) } \\ -0,6<\mathrm{Ab} / \mathrm{SN} \leq 0,6 & : & \text { Cukup kuat (positif/negatif) } \\ -1,8<\mathrm{Ab} / \mathrm{SN} \leq-0,6 & : & \text { Rendah (negatif) } \\ -3,0<\mathrm{Ab} / \mathrm{SN} \leq-1,8</, & \text { Sangat rendah (negatif) }\end{array}$

\section{HASIL PENELITIAN DAN PEMBAHASAN}

\section{A. Identitas Responden}

Identitas responden meliputi: jenis kelamin, umur, pendidikan, dan pekerjaan responden. Jumlah dan persentase identitas responden berdasarkan jenis kelamin disajikan pada tabel berikut:

Tabel 2. Jenis Kelamin Responden

\begin{tabular}{|l|l|l|}
\hline Jenis Kelamin Responden & Jumlah & Persen \\
\hline Pria & 68 & $72 \%$ \\
\hline Wanita & 27 & $28 \%$ \\
\hline Jumlah & 96 & $100 \%$ \\
\hline
\end{tabular}

Sumber: Diolah dari kuesioner

Tabel di atas menunjukkan bahwa responden mayoritas berjenis kelamin pria, karena sepeda motor Honda Absolute Revo lebih banyak digunakan kaum pria daripada wanita.

Tabel 3. Umur Responden

\begin{tabular}{|l|c|c|}
\hline Umur Responden (tahun) & Jumlah & Persen \\
\hline $15-30$ & 60 & $62 \%$ \\
\hline
\end{tabular}




\begin{tabular}{|l|c|c|}
\hline $31-45$ & 19 & $20 \%$ \\
\hline $46-60$ & 15 & $16 \%$ \\
\hline$>60$ & 2 & $2 \%$ \\
\hline Jumlah & 96 & $100 \%$ \\
\hline
\end{tabular}

Sumber: Diolah dari hasil kuesioner

Tabel di atas menunjukkan bahwa responden mayoritas berumur antara 15-30 tahun, dan keinginan untuk memiliki sepeda motor cukup tinggi pada umur tersebut.

Tabel 4. Pendidikan Responden

\begin{tabular}{|l|c|c|}
\hline Pendidikan Responden & Jumlah & Persen \\
\hline SD & 17 & $18 \%$ \\
\hline SLTP & 26 & $27 \%$ \\
\hline SMU/Sederajat & 39 & $41 \%$ \\
\hline Perguruan Tinggi UDI & 14 & $14 \%$ \\
\hline Jumlah & 96 & $100 \%$ \\
\hline
\end{tabular}

Sumber: Diolah dari hasil kuesioner

Tabel di atas menunjukkan responden mayoritas berpendidikan SMU/sederajat. Hal ini menggambarkan bahwa yang berkeinginan untuk memiliki sepeda motor adalah responden yang berpendidikan SMU/sederajat.

Tabel 5. Pekerjaan Responden

\begin{tabular}{|l|l|c|}
\hline \multicolumn{1}{|c|}{ Pekerjaan Responden } & Jumlah & Persen \\
\hline Wiraswasta & 51 & $53 \%$ \\
\hline Pegawai Negeri Sipil (PNS) & 19 & $20 \%$ \\
\hline Pegawai Swasta & 14 & $15 \%$ \\
\hline Lain-lain & 12 & $12 \%$ \\
\hline Jumlah & 96 & $100 \%$ \\
\hline
\end{tabular}

Sumber: Diolah dari hasil kuesioner

Tabel di atas menunjukkan responden mayoritas bekerja sebagai wiraswasta. Hal ini berarti bahwa sepeda motor Honda Absolute Revo sesuai untuk kegiatan usahanya, karena keiritan pemakaian bahan bakar minyak, harga jual kembali tinggi, dan kemudahan perawatan.

\section{B. Hasil Uji Validitas dan Reliabilitas}

Berdasarakan hasil pengolahan data dengan menggunakan program SPSS (Statistical Program for Social Sciences) versi 17,0 diperoleh hasil uji validitas secara simultan mengenai variabel Keyakinan $\left(b_{i}\right)$, Evaluasi $\left(e_{i}\right)$, Keyakinan Normatif $(N B j)$, Motivasi $(M C)$ masyarakat disajikan pada tabel berikut:

Tabel 6. Case Processing Summmary

\begin{tabular}{|c|c|c|c|}
\hline Cases & Valid & $\mathbf{N}$ & $\mathbf{\%}$ \\
\hline & Excluded $^{a}$ & 30 & 100.0 \\
\hline & Total & 0 & .0 \\
\hline & & 30 & 100.0 \\
\hline
\end{tabular}

Listwise deletion based on all variables in the procedure

Dari tabel di atas menunjukkan dari pengamatan 30 responden, 100\% dinyatakan sudah valid.

Hasil uji reliabilitas secara simultan mengenai variabel Keyakinan ( $\left.b_{i}\right)$, Evaluasi $\left(e_{i}\right)$, Keyakinan Normatif (NBj), Motivasi (MC) masyarakat disajikan pada tabel berikut: 
Tabel 7. Reliability Statistics

\begin{tabular}{|c|c|}
\hline Cronbach's Alpha & N of Items \\
\hline .924 & 32 \\
\hline
\end{tabular}

Dari tabel di atas menunjukkan instrumen pengukuran variabel Keyakinan $\left(b_{i}\right)$, Evaluasi $\left(\mathrm{e}_{\mathrm{i}}\right)$, Keyakinan Normatif (NBj), Motivasi (MC) sudah reliabel karena nilai cronbach's alpha sebesar 0,924 >0,50. Selanjutnya disajikan hasil uji validitas dan reliabilitas secara parsial pada tabel berikut :

Tabel 8. Item Total Statistics

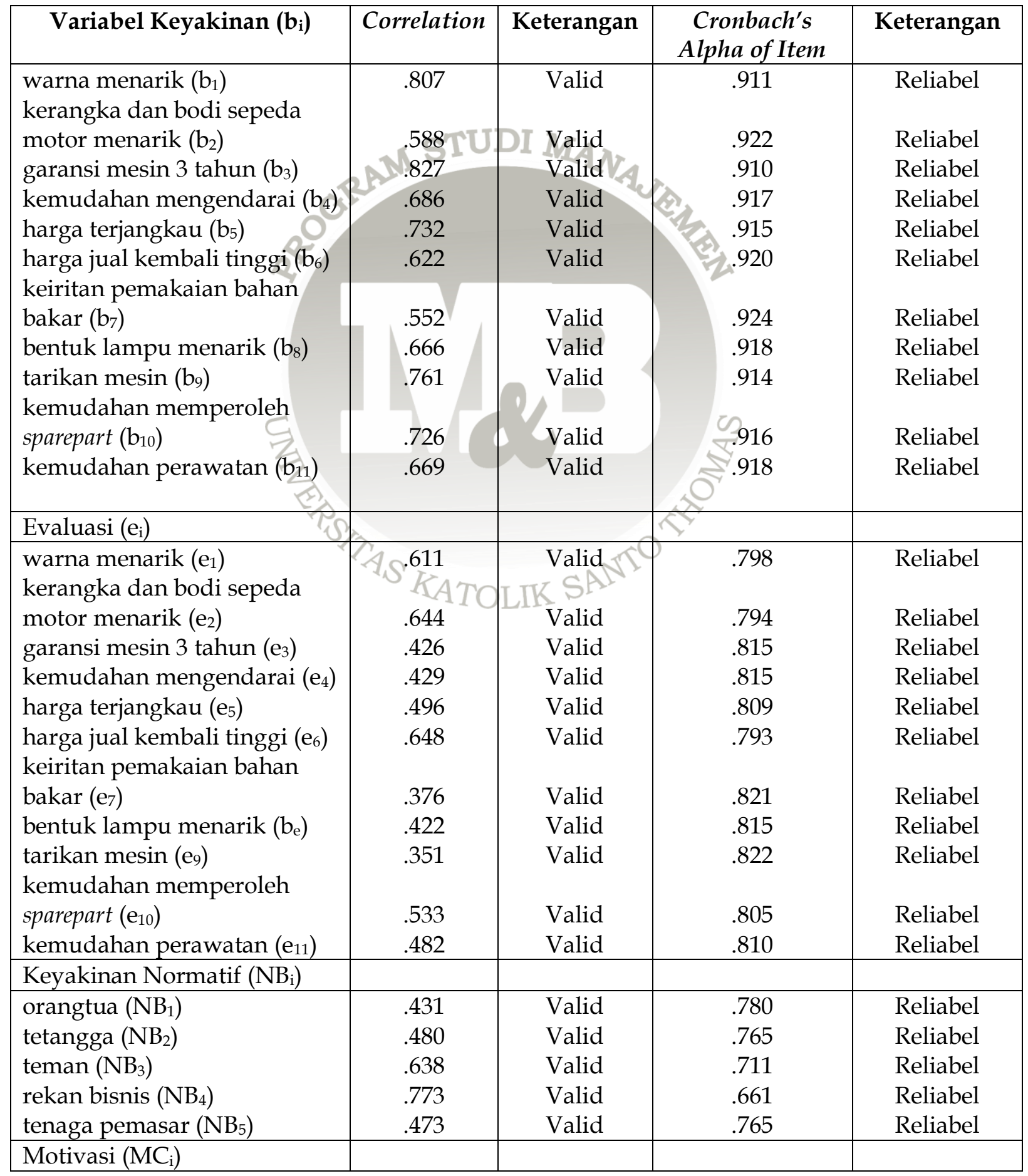


Volume 18 Nomor 2

\begin{tabular}{|l|c|c|c|c|}
\hline \multicolumn{1}{|c|}{ Variabel Keyakinan $\left(\mathbf{b}_{\mathbf{i}}\right)$} & Correlation & Keterangan & $\begin{array}{c}\text { Cronbach's } \\
\text { Alpha of Item }\end{array}$ & Keterangan \\
\hline orangtua $\left(\mathrm{MC}_{1}\right)$ & .738 & Valid & .783 & Reliabel \\
tetangga $\left(\mathrm{MC}_{2}\right)$, & .583 & Valid & .835 & Reliabel \\
teman $\left(\mathrm{MC}_{3}\right)$ & .718 & Valid & .799 & Reliabel \\
rekan bisnis $\left(\mathrm{MC}_{4}\right)$ & .530 & Valid & .847 & Reliabel \\
tenaga pemasar $\left(\mathrm{MC}_{5}\right)$ & .719 & Valid & .799 & Reliabel \\
\hline
\end{tabular}

Dari tabel di atas, terlihat bahwa setiap atribut pengukuran variabel Keyakinan $\left(b_{i}\right)$, Evaluasi ( $\mathrm{e}_{\mathrm{i}}$ ), Keyakinan Normatif (NBj), Motivasi (MC) secara rata-rata sudah valid karena nilai $\mathrm{r}_{\text {hitung }}>$ 0,30 dan reliable, karena nilai Cronbach's Alpha if Item lebih besar dari 0,50.

\section{Variabel Keyakinan Berperilaku $\left(b_{i}\right)$}

Keyakinan berperilaku $\left(b_{i}\right)$ merupakan keyakinan responden bahwa jika membeli sepeda motor Honda Absolute Revo akan memperoleh manfaat. Manfaat tersebut adalah warna menarik $\left(b_{1}\right)$, kerangka dan bodi sepeda motor menarik $\left(b_{2}\right)$, garansi mesin 3 tahun $\left(b_{3}\right)$, kemudahan mengendarai $\left(b_{4}\right)$, harga terjangkau $\left(b_{5}\right)$ harga jual kembali tinggi $\left(b_{6}\right)$, keiritan pemakaian bahan bakar $\left(b_{7}\right)$, bentuk lampu menarik $\left(b_{8}\right)$, tarikan mesin $\left(b_{9}\right)$, kemudahan memperoleh sparepart $\left(b_{10}\right)$, dan kemudahan perawatan $\left(b_{11}\right)$. Nilai atribut keyakinan berperilaku masyarakat Kelurahan Bantan, Kecamatan Medan Tembung-Medan disajikan pada tabel 9 .

Tabel 9. Nilai Atribut Variabel Keyakinan Berperilaku Masyarakat Kelurahan Bantan, Kecamatan Medan Tembung-Medan

\begin{tabular}{|c|c|c|c|c|c|c|c|c|}
\hline $\begin{array}{c}\text { Sub } \\
\text { Atribut }\end{array}$ & $\begin{array}{l}\text { SS } \\
(3)\end{array}$ & $\begin{array}{l}S \\
(2)\end{array}$ & $\begin{array}{l}\text { AS } \\
\text { (1) }\end{array}$ & $\begin{array}{c}\text { ATS } \\
(-1)\end{array}$ & $\begin{array}{l}\text { TS } \\
(-2)\end{array}$ & $\begin{array}{c}\text { STS } \\
(-3)\end{array}$ & $\begin{array}{l}\text { Rata-rata } \\
\text { Tertimbang }\end{array}$ & Penilaian \\
\hline$b_{1}$ & 4 & 38 & 29 & 8 & 15 & 2 & 0,76 & Positif/kuat \\
\hline$b_{2}$ & 4 & 37 & 29 & 11 & 14 & 1 & 0,76 & Positif/kuat \\
\hline$b_{3}$ & 5 & 46 & 19 & KA10 & 16 & 0 & 0,88 & Positif/kuat \\
\hline $\mathrm{b}_{4}$ & 7 & 33 & 31 & 9 & 16 & 0 & 0,80 & Positif/kuat \\
\hline$b_{5}$ & 8 & 49 & 18 & 8 & 9 & 4 & 1,06 & Positif/kuat \\
\hline$b_{6}$ & 9 & 46 & 21 & 7 & 11 & 2 & 1,09 & Positif/kuat \\
\hline$b_{7}$ & 20 & 34 & 16 & 8 & 17 & 1 & 1,03 & Positif/kuat \\
\hline$b_{8}$ & 14 & 35 & 19 & 10 & 16 & 2 & 0,86 & Positif/kuat \\
\hline$b_{9}$ & 9 & 31 & 36 & 6 & 13 & 1 & 0,94 & Positif/kuat \\
\hline $\mathrm{b}_{10}$ & 10 & 40 & 23 & 6 & 17 & 0 & 0,97 & Positif/kuat \\
\hline$b_{11}$ & 12 & 48 & 20 & 2 & 14 & 0 & 1,27 & Positif/kuat \\
\hline Total & - & - & - & - & - & - & 10,43 & - \\
\hline $\begin{array}{l}\text { Rata- } \\
\text { rata }\end{array}$ & - & - & - & - & - & - & 0,95 & Positif/kuat \\
\hline
\end{tabular}

Sumber: Diolah dari hasil kuesioner

Berdasarkan tabel di atas, rata-rata tertimbang dihitung dengan cara mengalikan antara total jawaban respoden untuk tiap alternatif dengan alternatif pilihan jawaban, dibagi dengan jumlah respoden. Misalnya rata-rata tertimbang skor jawaban respoden mengenai warna menarik $\left(\mathrm{e}_{1}\right)$ adalah:

Rata-rata tertimbang $=\frac{(4 \times 3)+(38 \times 2)+(29 \times 1)+(8 \times-1)+(15 \times-2)+(2 \times-3)}{96}=0,76$

Dari tabel di atas, diketahui secara rata-rata masyarakat Kelurahan Bantan, Kecamatan Medan Tembung-Medan memiliki keyakinan positif (kuat) untuk membeli sepeda motor Analisis Sikap dan Norma Subyektif Terhadap Perilaku Konsumen untuk Membeli Sepeda Motor 144 Honda Absolute Revo (Studi Kasus: Masyarakat Kelurahan Bantan, Kecamatan Medan Tembung). 
Honda Absolute Revo. Faktor yang paling dominan mempengaruhi keyakinan berperilaku masyarakat untuk membeli sepeda motor Honda Absolute Revo adalah harga terjangkau ( $\left.b_{5}\right)$, harga jual kembali tinggi $\left(b_{6}\right)$, keiritan pemakain bahan bakar $\left(b_{7}\right)$, dan kemudahan perawatan $\left(b_{11}\right)$.

\section{Evaluasi $\left(\mathbf{e}_{\mathbf{i}}\right)$}

Evaluasi merupakan variabel yang menunjukkan evaluasi masyarakat sebelum membeli sepeda motor akan manfaat atribut yang ditawarkan oleh sepeda motor Honda Absolute Revo. Manfaat tersebut adalah warna menarik $\left(\mathrm{e}_{1}\right)$, kerangka dan bodi sepeda motor menarik $\left(\mathrm{e}_{2}\right)$, garansi mesin 3 tahun $\left(\mathrm{e}_{3}\right)$, kemudahan mengendarai $\left(\mathrm{e}_{4}\right)$, harga terjangkau $\left(\mathrm{e}_{5}\right)$ harga jual kembali tinggi $\left(\mathrm{e}_{6}\right)$, keiritan pemakaian bahan bakar $\left(\mathrm{e}_{7}\right)$, bentuk lampu menarik $\left(b_{e}\right)$, tarikan mesin $\left(e_{9}\right)$, kemudahan memperoleh sparepart $\left(\mathrm{e}_{10}\right)$, dan kemudahan perawatan $\left(\mathrm{e}_{11}\right)$. Nilai atribut variabel evaluasi keyakinan masyarakat Kelurahan Bantan, Kecamatan Medan Tembung-Medan disajikan pada Tabel 10 dibawah ini.

Tabel 10. Nilai Atribut Variabel Evaluasi Keyakinan Masyarakat Kelurahan Bantan, Kecamatan Medan Tembung-Medan

\begin{tabular}{|c|c|c|c|c|c|c|c|c|}
\hline \multirow{2}{*}{$\begin{array}{c}\text { Sub } \\
\text { Variabel }\end{array}$} & SS & $\mathrm{S}$ & AS & ATS & TS & STS & \multirow{2}{*}{$\begin{array}{l}\text { Rata-rata } \\
\text { tertimbang }\end{array}$} & \multirow{2}{*}{ Penilaian } \\
\hline & (3) & & (1) & $(-1)$ & $(-2)$ & $(-3)$ & & \\
\hline $\mathrm{e}_{1}$ & 1 & 35 & 38 & 9 & 8 & 5 & 0,74 & Kuat/positif \\
\hline $\mathrm{e}_{2}$ & 5 & 46 & 23 & 6 & 14 & 2 & 0,94 & Kuat/positif \\
\hline $\mathrm{e}_{3}$ & 8 & 33 & 36 & 4 & 8 & 7 & 0,89 & Kuat/positif \\
\hline $\mathrm{e}_{4}$ & 6 & 35 & 37 & 5 & 9 & 4 & 0,94 & Kuat/positif \\
\hline $\mathrm{e}_{5}$ & 11 & 39 & 26 & 7 & 11 & 2 & 1,06 & Kuat/positif \\
\hline $\mathrm{e}_{6}$ & 12 & 39 & 24 & 11 & 70 & 3 & 1,08 & Kuat/positif \\
\hline $\mathrm{e}_{7}$ & 10 & 43 & 25 & 2 & 15 & 1 & 1,10 & Kuat/positif \\
\hline $\mathrm{e}_{8}$ & 7 & 36 & 30 & 10 & 9 & 4 & 0,86 & Kuat/positif \\
\hline $\mathrm{e}_{9}$ & 6 & 29 & 33 & 9 & 15 & 4 & 0,60 & Kuat/positif \\
\hline $\mathrm{e}_{10}$ & 13 & 35 & 22 & 11 & 10 & 5 & 0,89 & Kuat/positif \\
\hline$e_{11}$ & 9 & 35 & 29 & $7 k$ & 14 & $2 S$ & 0,89 & Kuat/positif \\
\hline Jumlah & - & - & - & - & - & - & 9,99 & - \\
\hline Rata-rata & - & - & - & - & - & - & 0,91 & Kuat/positif \\
\hline
\end{tabular}

Sumber: Diolah dari hasil kuesioner

Berdasarkan tabel di atas, rata-rata tertimbang dihitung dengan cara mengalikan antara total jawaban respoden untuk tiap alternatif dengan alternatif pilihan jawaban, dibagi dengan jumlah respoden. Misalnya rata-rata tertimbang skor jawaban respoden mengenai warna menarik $\left(\mathrm{e}_{1}\right)$ adalah:

Rata-rata tertimbang $=\frac{(1 \times 3)+(35 \times 2)+(38 \times 1)+(9 \times-1)+(8 \times-2)+(5 \times-3)}{96}=0,74$

Dari tabel di atas, diketahui secara rata-rata masyarakat Kelurahan Bantan, Kecamatan Medan Tembung-Medan memberikan evaluasi yang positif (kuat) untuk membeli sepeda motor Honda Absolute Revo. Faktor yang paling dominan mempengaruhi evaluasi masyarakat untuk membeli sepeda motor Honda Absolute Revo adalah harga terjangkau ( $\left.\mathrm{e}_{5}\right)$, harga jual kembali tinggi $\left(\mathrm{e}_{6}\right)$, dan keiritan pemakain bahan bakar $\left(\mathrm{e}_{7}\right)$.

E. Sikap masyarakat $(\mathrm{Ab})$

Sikap masyarakat $(\mathrm{Ab})$ merupakan variabel yang menunjukkan sikap masyarakat Kelurahan Bantan, Kecamatan Medan Tembung-Medan terhadap minat untuk membeli sepeda motor Honda Absolute Revo. Sikap masyarakat diperoleh dari hasil perkalian antara nilai keyakinan $\left(b_{i}\right)$ dengan variabel evaluasi $\left(e_{i}\right)$. Nilai atribut dari variabel sikap masyarakat Kelurahan Bantan, Kecamatan Medan Tembung-Medan disajikan pada Tabel 11 dibawah ini. 
Tabel 11. Nilai Sikap Masyarakat Kelurahan Bantan, Kecamatan Medan Tembung-Medan

\begin{tabular}{|c|c|c|c|c|}
\hline $\begin{array}{c}\text { Sub } \\
\text { Variabel }\end{array}$ & $\begin{array}{c}\text { Keyakinan } \\
\left(\mathbf{b}_{\mathbf{i}}\right)\end{array}$ & $\begin{array}{c}\text { Evaluasi } \\
\qquad\left(\mathrm{e}_{\mathrm{i}}\right)\end{array}$ & $\begin{array}{c}\text { Sikap } \\
\text { masyarakat } \\
(\mathrm{Ab})=\left(\mathrm{b}_{\mathrm{i}} \times \mathrm{e}_{\mathrm{i}}\right)\end{array}$ & Penilaian \\
\hline $\mathrm{Ab}_{1}$ & 0,76 & 0,74 & 0,56 & Cukup kuat/positif \\
\hline $\mathrm{Ab}_{2}$ & 0,76 & 0,94 & 0,71 & Kuat/positif \\
\hline $\mathrm{Ab}_{3}$ & 0,88 & 0,89 & 0,78 & Kuat/positif \\
\hline $\mathrm{Ab}_{4}$ & 0,80 & 0,94 & 0,75 & Kuat/positif \\
\hline $\mathrm{Ab}_{5}$ & 1,06 & 1,06 & 1,12 & Kuat/positif \\
\hline $\mathrm{Ab}_{6}$ & 1,09 & 1,08 & 1,18 & Kuat/positif \\
\hline $\mathrm{Ab}_{7}$ & 1,03 & 1,10 & 1,13 & Kuat/positif \\
\hline $\mathrm{Ab}_{8}$ & 0,86 & 0,86 & 0,74 & Kuat/positif \\
\hline $\mathrm{Ab}_{9}$ & 0,94 & 0,60 & 0,56 & Cukup kuat/positif \\
\hline$A b_{10}$ & 0,97 & 0,89 & 0,86 & Kuat/positif \\
\hline$A b_{11}$ & 1,27 & 0,89 & 1,13 & Kuat/positif \\
\hline Jumlah & 10,42 & 9,99 & 9,54 & - \\
\hline Rata-rata & 0,95 & 0,91 & 0,87 & Kuat/positif \\
\hline
\end{tabular}

Sumber: Diolah dari Tabel 9 dan Tabel 10

Dari tabel di atas, diketahui bahwa faktor yang paling dominan mempengaruhi sikap masyarakat untuk membeli sepeda motor Honda Absolute Revo adalah harga terjangkau $\left(A b_{5}\right)$, harga jual kembali tinggi $\left(\mathrm{Ab}_{6}\right)$, keiritan pemakaian bahan bakar $\left(\mathrm{Ab}_{7}\right)$, dan kemudahan perawatan $\left(A b_{11}\right)$.

\section{F. Keyakinan Normatif dari Kelompok Preferen $\left(\mathbf{N B}_{\mathbf{j}}\right)$}

Keyakinan normatif dari kelompok preferen $\left(\mathrm{NB}_{\mathrm{j}}\right)$ adalah gagasan yang diterima pembeli sepeda motor Honda Absolute Revo dari kelompok preferen. Kelompok preferen tersebut adalah orangtua $\left(\mathrm{NB}_{1}\right)$, tetangga $\left(\mathrm{NB}_{2}\right)$, teman $\left(\mathrm{NB}_{3}\right)$, rekan bisnis $\left(\mathrm{NB}_{4}\right)$, dan tenaga pemasar $\left(\mathrm{NB}_{5}\right)$. Nilai atribut variabel keyakinan dari kelompok preferen disajikan pada Tabel 12 dibawah ini.

Tabel 12. Nilai Atribut Variabel Keyakinan dari Kelompok Preferen Pada Masyarakat Kelurahan Bantan, Kecamatan Medan Tembung-Medan

\begin{tabular}{|c|c|c|c|c|c|c|c|c|}
\hline $\begin{array}{c}\text { Sub } \\
\text { Variabel }\end{array}$ & SS & S & AS & ATS & TS & STS & Rata-rata & Penilaian \\
\cline { 2 - 7 } & $\mathbf{( 3 )}$ & $\mathbf{( 2 )}$ & $\mathbf{( 1 )}$ & $\mathbf{( - 1 )}$ & $\mathbf{( - 2 )}$ & $\mathbf{( - 3 )}$ & Tertimbang & Kuat/positif \\
$\mathrm{NB}_{1}$ & 1 & 34 & 34 & 12 & 13 & 2 & 0,64 & Cukup kuat/positif \\
$\mathrm{NB}_{2}$ & 2 & 17 & 42 & 16 & 15 & 4 & 0,25 & Kuat/positif \\
$\mathrm{NB}_{3}$ & 4 & 36 & 36 & 6 & 12 & 2 & 0,88 & Kuat/positif \\
$\mathrm{NB}_{4}$ & 6 & 35 & 27 & 14 & 13 & 1 & 0,75 & Kuat/positif \\
$\mathrm{NB}_{5}$ & 3 & 35 & 35 & 7 & 12 & 4 & 0,74 & - \\
\hline Jumlah & - & - & - & - & - & - & 3,25 & Kuat/positif \\
Rata-rata & - & - & - & - & - & - & 0,65 & \\
\hline
\end{tabular}

Sumber: Diolah dari hasil kuesioner

Berdasarkan tabel di atas, rata-rata tertimbang dihitung dengan cara mengalikan antara total jawaban respoden untuk tiap alternatif dengan alternatif pilihan jawaban, dibagi dengan jumlah respoden. Misalnya rata-rata tertimbang skor jawaban respoden mengenai pengaruh orangtua $\left(\mathrm{NB}_{1}\right)$ adalah : 
Rata-rata tertimbang $=\frac{(1 \times 3)+(34 \times 2)+(34 \times 1)+(12 \times-1)+(13 \times-2)+(2 \times-3)}{96}=0,64$

Dari tabel di atas, diketahui secara rata-rata kelompok preferen memberikan pengaruh yang positif (kuat) terhadap pembelian sepeda motor Honda Absolute Revo. Faktor yang paling dominan mempengaruhi keyakinan dari kelompok preferen adalah teman $\left(\mathrm{NB}_{3}\right)$.

\section{G. Motivasi $\left(\mathrm{MC}_{\mathrm{j}}\right)$}

Motivasi $\left(\mathrm{MC}_{\mathrm{j}}\right)$ adalah dorongan yang diperoleh dari kelompok preferen untuk membeli sepeda motor Honda Absolute Revo. Kelompok preferen tersebut adalah orangtua $\left(\mathrm{MC}_{1}\right)$, tetangga $\left(\mathrm{MC}_{2}\right)$, teman $\left(\mathrm{MC}_{3}\right)$, rekan bisnis $\left(\mathrm{MC}_{4}\right)$, dan tenaga pemasar $\left(\mathrm{MC}_{5}\right)$. Nilai atribut variabel motivasi dari kelompok preferen disajikan pada Tabel 13 dibawah ini.

Tabel 13. Nilai Atribut Variabel Motivasi dari Kelompok Preferen untuk Membeli Sepeda Motor Honda Absolute Revo Pada Masyarakat Kelurahan Bantan, Kecamatan Medan Tembung-Medan

\begin{tabular}{|l|c|c|c|c|c|c|c|c|}
\hline \multirow{2}{*}{$\begin{array}{c}\text { Sub } \\
\text { Variabel }\end{array}$} & SS & S & AS & ATS & TS & STS & Rata-rata & Penilaian \\
\cline { 2 - 9 } & $\mathbf{( 3 )}$ & $\mathbf{( 2 )}$ & $\mathbf{( 1 )}$ & $\mathbf{( - 1 )}$ & $\mathbf{( - 2 )}$ & $\mathbf{( - 3 )}$ & Tertimbang & \\
\hline $\mathrm{MC}_{1}$ & 3 & 33 & 37 & 11 & 11 & 1 & 0,79 & Kuat/positif \\
$\mathrm{MC}_{2}$ & 1 & 17 & 34 & 12 & 28 & 4 & $-0,09$ & Cukup kuat/negatif \\
$\mathrm{MC}_{3}$ & 2 & 26 & 36 & 19 & 13 & 0 & 0,51 & Cukup kuat/negatif \\
$\mathrm{MC}_{4}$ & 2 & 29 & 40 & 14 & 11 & 0 & 0,71 & Kuat/positif \\
$\mathrm{MC}_{5}$ & 1 & 37 & 36 & 13 & 9 & 0 & 0,85 & Kuat/positif \\
\hline Jumlah & - & - & - & - & - & - & 2,77 & - \\
Rata-rata & - & - & - & - & - & - & 0,55 & Kuat/positif \\
\hline
\end{tabular}

Sumber: Diolah dari hasil kuesioner

Berdasarkan tabel di atas, rata-rata tertimbang dihitung dengan cara mengalikan antara total jawaban respoden untuk tiap alternatif dengan alternatif pilihan jawaban, dibagi dengan jumlah respoden. Misalnya rata-rata tertimbang skor jawaban respoden mengenai motivasi orangtua $\left(\mathrm{MC}_{1}\right)$ adalah :

Rata-rata tertimbang $=\frac{(3 \times 3)+(33 \times 2)+(37 \times 1)+(11 \times-1)+(11 \times-2)+(1 \times-3)}{96}=0,79$

Dari tabel di atas, diketahui secara rata-rata kelompok preferen memberikan motivasi yang positif (kuat) terhadap pembelian sepeda motor Honda Absolute Revo. Faktor yang paling dominan mempengaruhi motivasi masyarakat untuk membeli sepeda motor Honda Absolute Revo adalah tenaga pemasar $\left(\mathrm{MC}_{5}\right)$.

\section{H. Norma Subyektif (SN)}

Norma Subyektif (SN) merupakan variabel yang berhubungan dengan gagasan orang lain yang menghendaki masyarakat membeli sepeda motor Honda Absolute Revo. Norma Subyektif diperoleh dari hasil perkalian antara keyakinan normatif $\left(\mathrm{NB}_{\mathrm{j}}\right)$ dengan variabel motivasi $\left(\mathrm{MC}_{\mathrm{j}}\right)$. Nilai norma subyektif disajikan pada tabel berikut ini.

Tabel 14. Nilai Norma Subyektif Masyarakat Kelurahan Bantan, Kecamatan Medan

Tembung-Medan

\begin{tabular}{|c|c|c|c|c|}
\hline $\begin{array}{c}\text { Sub } \\
\text { Variabel }\end{array}$ & $\begin{array}{c}\text { Keyakinan } \\
\text { Normatif }\left(\mathrm{NB}_{\mathbf{j}}\right)\end{array}$ & $\begin{array}{c}\text { Motivasi } \\
\left(\mathrm{MC}_{\mathrm{j}}\right)\end{array}$ & $\begin{array}{l}\text { Norma Subyektif } \\
\left(\mathrm{NB}_{\mathbf{j}} \times \mathrm{MC}_{\mathrm{j}}\right)\end{array}$ & Penilaian \\
\hline $\mathrm{SN}_{1}$ & 0,64 & 0,79 & 0,51 & Cukup kuat/positif \\
\hline $\mathrm{SN}_{2}$ & 0,25 & $-0,09$ & $-0,02$ & Cukup kuat/positif \\
\hline $\mathrm{SN}_{3}$ & 0,88 & 0,51 & 0,45 & Cukup kuat/positif \\
\hline
\end{tabular}


Volume 18 Nomor 2

\begin{tabular}{|c|c|c|c|c|}
$\mathrm{SN}_{4}$ & 0,75 & 0,71 & 0,53 & Cukup kuat/positif \\
$\mathrm{SN}_{5}$ & 0,74 & 0,85 & 0,63 & Kuat/positif \\
\hline Jumlah & 3,26 & 2,77 & 2,09 & - \\
Rata-rata & 0,65 & 0,55 & 0,42 & Cukup kuat/positif \\
\hline
\end{tabular}

Sumber: Diolah dari Tabel 12 dan Tabel 13

Dari tabel di atas, diketahui bahwa faktor yang paling dominan mempengaruhi masyarakat untuk membeli sepeda motor Honda Absolute Revo adalah gagasan tenaga pemasar $\left(\mathrm{MC}_{5}\right)$.

\section{Minat Berperilaku}

Berdasarkan lampiran 2 diketahui total $b_{1}=1.001$, total $e_{1}=959$, total $N B j=312$, dan total $M C j=266$. Dengan demikian dapat dihitung W1 dan W2 sebagai berikut:

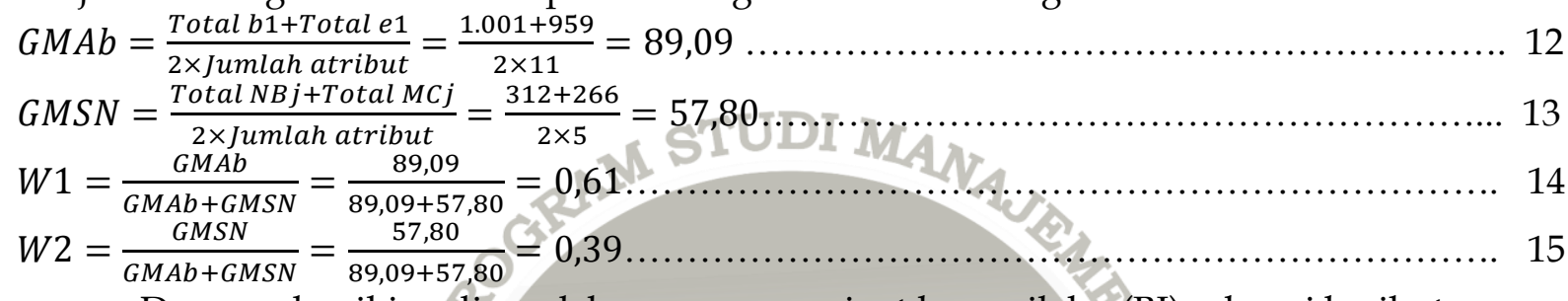

Dengan demikian diperoleh persamaan minat berperilaku(BI) sebagai berikut:

$(\mathrm{B}=\mathrm{BI})=\mathrm{W} 1 \mathrm{Ab}+\mathrm{W} 2 \mathrm{SN}$

$$
=0,61 \mathrm{Ab}+0,39 \mathrm{SN}
$$

Berdasarkan persamaan diatas menunjukkan bahwa ternyata minat berperilaku lebih besar dipengaruhi oleh sikap masyarakat Kelurahan Bantan, Kecamatan Medan TembungMedan sebesar 0,61 (61\%) dari norma subyektif 0,39 (39\%).

Pembahasan variabel penelitian yang terdiri dari tiga sub variabel yakni:

a. Tabel 14, menunjukkan bahwa sikap masyarakat Kelurahan Bantan, Kecamatan Medan Tembung-Medan secara rata-rata memberikan pengaruh yang positif (kuat) terhadap minat berperilaku. Faktor yang paling dominan mempengaruhi sikap masyarakat adalah harga terjangkau, harga jual kembali tinggi, keiritan pemakaian bahan bakar dan kemudahan perawatan.

b. Tabel 13, menunjukkan bahwa Kelurahan Bantan, Kecamatan Medan Tembung-Medan diyakinkan dan termotivasi dari kelompok preferen yang secara rata-rata memberikan pengaruh yang positif (kuat) terhadap minat berperilaku. Faktor yang paling dominan mempengaruhi norma subyektif adalah tenaga pemasar.

c. Berdasarkan persamaan minat berperilaku $=\mathrm{BI}=0,61 \mathrm{Ab}+0,39 \mathrm{SN}$. Artinya minat perilaku lebih besar dipengaruhi oleh sikap masyarakat sebesar 0,61 (61\%) dari norma subyektif 0,39 (39\%).

Berdasarkan uraian tersebut diatas, dapat disimpulkan bahwa sikap dan norma subyektif berpengaruh terhadap perilaku masyarakat Kelurahan Bantan, Kecamatan Medan Tembung-Medan dalam membeli sepeda motor Honda Absolute Revo.

\section{KESIMPULAN DAN SARAN}

Berdasarkan hasil pembahasan, maka dapat disimpulkan bahwa:

1. Rata-rata masyarakat Kelurahan Bantan, Kecamatan Medan Tembung-Medan memiliki keyakinan dan evaluasi yang kuat (positif) untuk membeli sepeda motor Honda Absolute Revo. Faktor yang paling dominan mempengaruhi keyakinan dan evaluasi masyarakat untuk membeli sepeda motor Honda Absolute Revo adalah harga terjangkau, harga jual kembali tinggi, keiritan pemakaian bahan bakar, dan kemudahan perawatan.

2. Rata-rata masyarakat Kelurahan Bantan, Kecamatan Medan Tembung-Medan bersikap positif (kuat) terhadap minat untuk membeli sepeda motor Honda Absolute Revo. Faktor 
yang paling dominan mempengaruhi sikap masyarakat adalah harga terjangkau, harga jual kembali tingi, keiritan pemakaian bahan bakar, dan kemudahan perawatan.

3. Rata-rata masyarakat Kelurahan Bantan, Kecamatan Medan Tembung-Medan memiliki keyakinan dan motivasi yang kuat (positif) dari kelompok preferen untuk membeli sepeda motor Honda Absolute Revo. Faktor yang paling dominan mempengaruhi keyakinan dan motivasi masyarakat adalah teman dan tenaga pemasar.

4. Rata-rata kelompok preferen memberikan pengaruh yang positif (kuat) kepada masyarakat untuk membeli sepeda motor Honda Absolute Revo. Faktor yang paling dominan mempengaruhi norma subyektif adalah tenaga pemasar.

\section{DAFTAR PUSTAKA}

Angipora, Marius P., 2002, Dasar-dasar Pemasaran, Edisi Kedua, Cetakan Kedua, Jakarta: PT Raja Grafindo Persada.

Boyd, Harper W; Walker, Orville dan Larrenche, Jean Claude, 2001. Manajemen Pemasaran: Suatu Pendekatan Strategis dengan Orientasi Global, Jilid 2, Alih Bahasa: Iman Nurmawan, Jakarta: Erlangga.

Candra, Gregorius, 2005. Strategi dan Program Pemasaran, Edisi Pertama, Cetakan Keempat, Yogyakarta: Andi.

Kotler, Philip dan Armstrog, Gary. 2001. Prinsip-prinsip Pemasaran, Jilid Satu, Alih Bahasa: Jaka Wasana, Edisi Kedelapan, Jakarta: Erlangga.

Kotler, Philip dan Armstrong, Gary. 2004. Dasar-dasar Pemasaran, Jilid Satu, Alih Bahasa: Alexander Sindoro, Edisi Kesembilan, Jakarta: Indeks.

Lamb, Charles W; Hair, JosephF., McDaniel, Carl. 2001. Pemasaran. Buku Satu, Alih Bahasa: David Octarevia, Edisi Pertama, Cetakan Pertama, Jakarta: Salemba Empat.

Ndraha, Taliziduhu, 2003. Budaya Organisasi. Edisi Pertama, Cetakan Pertama, Jakarta: Rineka Cipta.

Peter, Paul J dan Olson, Jerry C. 2001. Costumer Behavior: Perilaku Konsumen dan Strategi Pemasaran. Alih Bahasa: Damos Sihombing. Jakarta: Erlangga.

Sugiyono, 2005. Metode Penelitian Bisnis, Cetakan Keenam, Bandung: Alfabeta.

Supranto, J., 2001. Statistik: Teori dan Aplikasi, Jilid Dua, Edisi Keenam, Cetakan Pertama, Jakarta: Erlangga.

Sutisna, 2001. Perilaku Konsumen dan Komunikasi Pemasaran, Edisi Pertama, Jakarta: Rosda.

Umar, Husein, 2001. Studi Kelayakan Bisnis, Edisi Kedua, Cetakan Pertama, Yogyakarta: BPFE. 